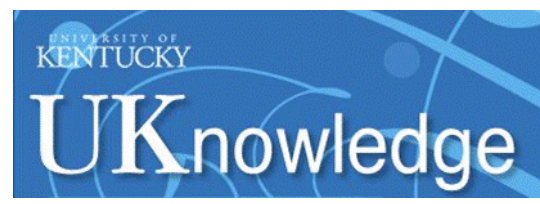

University of Kentucky

UKnowledge

$11-10-2014$

\title{
Grazing and No-Till Cropping Impacts on Nitrogen Retention in Dryland Agroecosystems
}

\author{
Megan L. Mobley \\ University of Wyoming \\ Rebecca L. McCulley \\ University of Kentucky, rebecca.mcculley@uky.edu \\ Ingrid C. Burke \\ University of Wyoming \\ Gary Peterson \\ Colorado State University, Fort Collins \\ David S. Schimel \\ California Institute of Technology
}

See next page for additional authors

Follow this and additional works at: https://uknowledge.uky.edu/pss_facpub

Part of the Plant Sciences Commons

Right click to open a feedback form in a new tab to let us know how this document benefits you.

\section{Repository Citation}

Mobley, Megan L.; McCulley, Rebecca L.; Burke, Ingrid C.; Peterson, Gary; Schimel, David S.; Cole, C. Vernon; Elliott, Edward T.; and Westfall, Dwayne G., "Grazing and No-Till Cropping Impacts on Nitrogen Retention in Dryland Agroecosystems" (2014). Plant and Soil Sciences Faculty Publications. 43. https://uknowledge.uky.edu/pss_facpub/43

This Article is brought to you for free and open access by the Plant and Soil Sciences at UKnowledge. It has been accepted for inclusion in Plant and Soil Sciences Faculty Publications by an authorized administrator of UKnowledge. For more information, please contact UKnowledge@lsv.uky.edu. 


\section{Grazing and No-Till Cropping Impacts on Nitrogen Retention in Dryland Agroecosystems}

Digital Object Identifier (DOI)

http://dx.doi.org/10.2134/jeq2013.12.0530

\section{Notes/Citation Information}

Published in Journal of Environmental Quality, v. 43, no. 6, p. 1963-1971.

This article is freely available online through the author-supported open-access option.

\section{Authors}

Megan L. Mobley, Rebecca L. McCulley, Ingrid C. Burke, Gary Peterson, David S. Schimel, C. Vernon Cole, Edward T. Elliott, and Dwayne G. Westfall 


\title{
Grazing and No-Till Cropping Impacts on Nitrogen Retention in Dryland Agroecosystems
}

\author{
Megan L. Mobley, ${ }^{*}$ Rebecca L. McCulley, Ingrid C. Burke, Gary Peterson, David S. Schimel, \\ C. Vernon Cole, Edward T. Elliott, and Dwayne G. Westfall
}

\begin{abstract}
As the world's population increases, marginal lands such as drylands are likely to become more important for food production. One proven strategy for improving crop production in drylands involves shifting from conventional tillage to no-till to increase water use efficiency, especially when this shift is coupled with more intensive crop rotations. Practices such as notill that reduce soil disturbance and increase crop residues may promote $\mathrm{C}$ and $\mathrm{N}$ storage in soil organic matter, thus promoting $\mathrm{N}$ retention and reducing $\mathrm{N}$ losses. By sampling soils $15 \mathrm{yr}$ after a ${ }^{15} \mathrm{~N}$ tracer addition, this study compared long-term soil $\mathrm{N}$ retention across several agricultural management strategies in current and converted shortgrass steppe ecosystems: grazed and ungrazed native grassland, occasionally mowed planted perennial grassland, and three cropping intensities of no-till dryland cropping. We also examined effects of the environmental variables site location and topography on $\mathrm{N}$ retention. Overall, the long-term soil $\mathrm{N}$ retention of $>18 \%$ in these managed semiarid ecosystems was high compared with published values for other cropped or grassland ecosystems. Cropping practices strongly influenced long-term $\mathrm{N}$ retention, with planted perennial grass systems retaining $>90 \%$ of ${ }^{15} \mathrm{~N}$ in soil compared with $30 \%$ for croplands. Grazing management, topography, and site location had smaller effects on long-term $\mathrm{N}$ retention. Estimated $15-\mathrm{yr} \mathrm{N}$ losses were low for intact and cropped systems. This work suggests that semiarid perennial grass ecosystems are highly $\mathrm{N}$ retentive and that increased intensity of semiarid land management can increase the amount of protein harvested without increasing $\mathrm{N}$ losses.
\end{abstract}

Copyright $\odot$ American Society of Agronomy, Crop Science Society of America, and Soil Science Society of America. 5585 Guilford Rd., Madison, WI 53711 USA. All rights reserved. No part of this periodical may be reproduced or transmitted in any form or by any means, electronic or mechanical, including photocopying, recording, or any information storage and retrieval system, without permission in writing from the publisher.

J. Environ. Qual. 43:1963-1971 (2014)

doi:10.2134/jeq2013.12.0530

Supplemental material is available online for this article.

Freely available online through the author-supported open-access option.

Received 31 Dec. 2013.

*Corresponding author (meg.mobley@alumni.duke.edu).


LOBAL FOOD production depends on management of water and nitrogen $(\mathrm{N})$ inputs. Management of these resources is particularly challenging in semiarid to arid agricultural landscapes where irrigation is not feasible and where agricultural producers must depend solely on rainwater. Seventyfive percent of the world's arable soils and 38\% of the world's population occur in these drylands-both rangelands and croplands-where lack of moisture limits plant production (Stewart et al., 2006). Although the Green Revolution increased production in irrigated and sufficiently rain-fed areas, unirrigated dryland regions were largely unaffected and have considerable room for improvement in productivity (Stewart et al., 2006). Closure of these yield gaps could increase global food production by 28 to $58 \%$ (Foley et al., 2011). As the world's population increases, these marginal lands are likely to become much more important for food production.

One strategy for improving production in cropped drylands involves shifting from conventional tillage to no-till agriculture, which can increase water use efficiency and crop yield, especially when coupled with more intensive crop rotations (Bonfil et al., 1999; Hatfield et al., 2001; McGee et al., 1997; Peterson and Westfall, 2004). However, maintaining greater productivity over time requires increased $\mathrm{N}$ additions, and it is unclear how $\mathrm{N}$ additions in semiarid regions affect the soil $\mathrm{N}$ cycle of these systems, many of which were formerly grasslands (Foley et al., 2011). One metric with which to compare $\mathrm{N}$ cycles of different ecosystems is the residence time of soil $\mathrm{N}$, or $\mathrm{N}$ retention, which depends on the size of the soil $\mathrm{N}$ pool and the rate of soil $\mathrm{N}$ cycling (Barrett and Burke, 2002). High $\mathrm{N}$ retention indicates a system with small $\mathrm{N}$ losses; in an agricultural context,

M.L. Mobley and I.C. Burke, Haub School of the Environment and Natural Resources, Dep. of Botany, Dep. of Ecosystem Science and Management, and Program in Ecology, Univ. of Wyoming, Laramie, WY 82071; R.L. McCulley, Dep. of Plant \& Soil Sciences, Univ. of Kentucky, Lexington, KY 40546-0091; G. Peterson and D.G. Westfall, Dep. of Soil and Crop Sciences, Colorado State Univ., Fort Collins, CO 80523; D.S. Schimel, Jet Propulsion Laboratory, California Institute of Technology, Pasadena, CA 91109; C.V. Cole (deceased) and E.T. Elliott (deceased), Natural Resource Ecology Laboratory, Colorado State Univ., Fort Collins, CO 80523; C.V. Cole (deceased), USDA Agricultural Research Service, Fort Collins, CO 80521. Assigned to Associate Editor Rota Wagai.

Abbreviations: CPOM, coarse particulate organic matter; FPOM, fine particulate organic matter; NUE, nitrogen use efficiency; PET, potential evapotranspiration; POM, particulate organic matter; SGS-LTER, Shortgrass Steppe Long-Term Ecological Research; SOM, soil organic matter; WCF, wheat-corn-fallow; WCMF, wheat-corn-millet-fallow; WF, wheat-fallow. 
this suggests efficient $\mathrm{N}$ use and prevention of greenhouse gas emissions and downstream eutrophication.

In grasslands, temperature, precipitation, and soil texture control the size of soil organic matter (SOM) and soil $\mathrm{N}$ pools (Burke et al., 1989; Evans et al., 2011; Miller et al., 2004; Paruelo et al., 1998). However, conversion of grasslands to agriculture can override these environmental controls and speed up the $\mathrm{N}$ cycle by greatly enhancing $\mathrm{N}$ inputs via fertilizer, by increasing plant $\mathrm{N}$ demand through the replacement of $\mathrm{N}$-use-efficient perennial native grasses with $\mathrm{N}$-demanding annual cultivated crops (Gardner and Drinkwater, 2009), and by accelerating decomposition and associated $\mathrm{N}$ losses. In general, $\mathrm{N}$ inputs to and exports from croplands exceed those of rangelands by an order of magnitude, as do $\mathrm{N}$ losses to the environment, as indicated by the difference between measured $\mathrm{N}$ inputs and exports (Burke et al., 2002). The greater $\mathrm{N}$ losses suggest that $\mathrm{N}$ retention is much lower for croplands than for rangelands. This reduced $\mathrm{N}$ retention limits the ability of the ecosystem to buffer $\mathrm{N}$ losses to downstream ecosystems.

Agricultural practices, such as no-till, that reduce soil disturbance and increase residues may promote $\mathrm{C}$ and $\mathrm{N}$ storage in SOM (Matson et al., 1997; West and Post, 2002). Soil organic matter plays an important role in $\mathrm{N}$ retention (Barrett and Burke, 2002); thus, management strategies, such as no-till and rotational cropping, that promote higher SOM content may promote $\mathrm{N}$ retention and reduce $\mathrm{N}$ losses. However, crop and $\mathrm{N}$ removals from intensive crop rotations are much higher than for conventional tillage agricultural systems, which may reduce soil $\mathrm{N}$ retention. Comparisons of long-term soil $\mathrm{N}$ retention and loss have rarely been made for different dryland agroecosystem management strategies.

The objective of our study was to compare long-term soil N retention across several agricultural management strategies in current and converted shortgrass steppe ecosystems: grazed and ungrazed native grassland, occasionally mowed planted perennial grassland, and three cropping intensities of no-till dryland cropping. Using a long-term ${ }^{15} \mathrm{~N}$ tracer study (Clark, 1977), we asked the following questions: (i) What is the influence of dryland agricultural management type and intensity on soil $\mathrm{N}$ retention and the ecosystem $\mathrm{N}$ balance? and (ii) How do the effects of management type and intensity compare with variation imposed by topography and regional location? We hypothesized that $\mathrm{N}$ retention would decline with increasing rates of biomass removal and increase with increasing rates of residue return: ungrazed grassland would have higher $\mathrm{N}$ retention than grazed grassland, intact grasslands would have higher $\mathrm{N}$ retention than cropped systems, and $\mathrm{N}$ retention would increase with cropping intensity and residue return in cropped systems.

\section{Materials and Methods}

\section{Site Description}

The shortgrass steppe occupies the warmest, driest, and least productive portion of the U.S. Great Plains; analogous ecosystems can also be found in South America and Asia (Evans et al., 2011; Paruelo et al., 1998). Over 70\% of shortgrass steppe remains in natural vegetation and is primarily managed for grazing (Lauenroth and Burke, 2008). What land has been converted is used for irrigated or dryland row crop agriculture.
The Shortgrass Steppe Long-Term Ecological Research (SGSLTER) site includes 6280 ha of eastern Colorado shortgrass steppe and is located approximately $8 \mathrm{~km}$ north of Nunn, CO $\left(40.82^{\circ} \mathrm{N}, 107.78^{\circ} \mathrm{W}\right)$. Within the SGS-LTER, the Central Plains Experimental Range is managed by the USDA-ARS and has supported long-term grazing experiments since 1938. Mean annual temperature is $8.6^{\circ} \mathrm{C}$, mean annual precipitation is 321 $\mathrm{mm}$ (primarily falling between May and Sept.), mean annual PET is approximately $1200 \mathrm{~mm}$, mean elevation is $1650 \mathrm{~m}$, and Aridic Argiustoll soils are sandy loam in texture (Lauenroth and Burke, 2008). The dominant native grass species are the $\mathrm{C}_{4}$ species Bouteloua gracilis (Willd. ex. Kunth) Lagasca ex Griffiths and Buchloe dactyloides (Nutt) Engelm. (Lauenroth and Burke, 2008). This experiment was performed in two adjacent 130-ha pastures, one ungrazed and one heavily grazed since 1938 (Burke et al., 1999). Until 1964, the heavily grazed pasture was managed such that $60 \%$ of aboveground biomass was removed by the end of each growing season; since 1965, the heavily grazed treatment has been managed to leave $22.5 \mathrm{~g} \mathrm{~m}^{-2}$ residual biomass at the end of the season (Milchunas et al., 2008). The cattle stocking rate averaged 1.3 yearlings ha ${ }^{-1} \mathrm{mo}^{-1}$ (Bement, 1969; Milchunas et al., 2008). Each pasture included three gently rolling toposequences in a north-south direction, each with three topographic positions: summit, midslope, and toeslope. Prior studies have shown many aspects of semiarid shortgrass steppe biogeochemistry to be relatively insensitive to human management practices, at least at decadal timescales (Burke et al., 1999; Lauenroth and Burke, 2008; Milchunas et al., 1998), but these studies have illustrated that topographic position plays an important role in determining SOM dynamics in this system (Yonker et al., 1988). Therefore, we evaluated the differences between summit and toeslope positions in this study. Management of these pastures is described in detail elsewhere (Burke et al., 1999).

The dryland cropping experiment was initiated in eastern Colorado in 1985 and is described in detail elsewhere (Peterson and Westfall, 2004). The sites included in this study, near Sterling $\left(40.37^{\circ} \mathrm{N}, 103.13^{\circ} \mathrm{W}\right)$ and Stratton $\left(39.18^{\circ} \mathrm{N}, 102.26^{\circ} \mathrm{W}\right)$, Colorado, both averaged $400 \mathrm{~mm} \mathrm{yr}^{-1}$ precipitation but differed in potential evapotranspiration (PET): average annual PET at Stratton (the southern site) is $\sim 1300 \mathrm{~mm}$, whereas annual PET at Sterling (the northern site) is $\sim 1000 \mathrm{~mm}$ (Peterson and Westfall, 2004). Soils were Aridic Argiustolls. In the year before planting the experimental treatments, the Sterling site had been planted to wheat, and the Stratton site had been in fallow. Wheat was planted in all rotations and sites in the fall of 1985 using no-till techniques. The perennial grass $(G)$ treatment was seeded with Agropyron desertorum (Fischer ex Link) Shultes, Agropyron smithii (Rydb.) Love, Bouteloua curtipendula (Michaux) Torrey, B. gracilis, B. dactyloides, and Schizachyrium scoparium (Michaux) Nash in spring 1986 (Peterson et al., 1993). The G treatment was never fertilized and was only harvested in years of sufficient biomass ( 3 out of $15 \mathrm{yr}$ ). Crop rotations were annually fertilized at planting with $\mathrm{N}$ (urea- $\mathrm{NH}_{4} \mathrm{NO}_{3}$ solution, $32-0-0 ; \delta^{15} \mathrm{~N} \sim 0$ ) (Xue et al., 2009) according to soil test recommendations. Crop rotation treatments were as follows: wheat-fallow (WF), wheatcorn-fallow (WCF), and wheat-corn-millet-fallow (WCMF). Year-to-year variations and substitutions in crop rotations are described in Supplemental Table S1. Past work at these sites has 
shown few differences in soil $\mathrm{C}$ and $\mathrm{N}$ pools or mineralization rates among treatments (Burke et al., 1995; Ortega et al., 2005).

The long-term $\mathrm{N}$ budget for the SGS-LTER site was adapted from a previous publication describing major $\mathrm{N}$ inputs $(\mathrm{N}$ deposition) and losses (cattle biomass removal) (Burke et al., 2008). We constructed a 15 -yr budget of $\mathrm{N}$ inputs ( $\mathrm{N}$ deposition, fertilizer) and losses (crop removals) for the dryland cropping treatments from records of annual fertilizer application, grain and stover harvest, and percent $\mathrm{N}$ and percent moisture of harvested grain and stover. These data were available at the level of site $\times$ treatment, not plot. The annual data and data sources for the dryland cropping $\mathrm{N}$ budget are presented in the supplemental information. The $\mathrm{N}$ deposition value measured on-site at the SGS-LTER site was applied for all sites and treatments. These budgets do not include erosional, deep leaching, or trace gas fluxes of $\mathrm{N}$ that are reflected in ${ }^{15} \mathrm{~N}$ retention measurements but are difficult to quantify. Previous work at the agricultural sites has shown deep leaching of $\mathrm{NO}_{3}$ to be minimal, with an accumulation of $\leq 12.6 \mathrm{~g} \mathrm{~m}^{-2}$ to $9 \mathrm{~m}$ depth after over $50 \mathrm{yr}$ of dryland agricultural cultivation (Evans et al., 1994).

\section{Tracer Application, Sampling, and Analysis Methods}

Plots were labeled with $2 \mathrm{~g}^{15} \mathrm{Nm}^{-2}$ [78.2 atom \% $\left.\left({ }^{15} \mathrm{NH}_{4}\right)_{2} \mathrm{SO}_{4}\right]$ in three increments in March, April, and May 1988. Each increment consisted of $0.626 \mathrm{~g}{ }^{15} \mathrm{~N}\left[3.62 \mathrm{~g}\left({ }^{15} \mathrm{NH}_{4}\right)_{2} \mathrm{SO}_{4}\right]$ in 2.5 $\mathrm{L}$ (equivalent to $1 / 4 \mathrm{~cm}$ ) water followed by another $2.5 \mathrm{~L}$ water. Solutions were applied to $0.939 \mathrm{~m}^{2}(122 \mathrm{~cm} \times 77 \mathrm{~cm})$ plots in 1/5-plot sections to ensure even application. At the SGS-LTER site, tracer was applied to three replicate plots on the summits and toeslopes (topographic positions) of each of three hillslope catenary sequences in both grazed and ungrazed treatments (2 treatments $\times 3$ toposequences $\times 2$ positions $\times 3$ replicate plots $=36$ total plots). At the agricultural experiment sites, tracer was applied to three $0.939-\mathrm{m}^{2}$ plots each on summit positions of two planting strips per each treatment (G, WF, WCF, WCMF) at the two sites $(2$ sites $\times 4$ treatments $\times 2$ strips $\times 3$ replicate plots $=$ 48 total plots). For the first $4 \mathrm{yr}$, the grain and stover from tracer plots was harvested by hand before the rest of the field, and the plots were covered during the harvest of the rest of the field to prevent contamination of tracer plots with plant material or soil from the unlabeled surroundings.

Plots were resampled in May 2003. Soil cores of $5 \mathrm{~cm}$ diameter were collected in $0-$ to $10-\mathrm{cm}$ and $10-$ to $30-\mathrm{cm}$ increments from $0.6-\mathrm{m}^{2}$ plots within the $0.929-\mathrm{m}^{2}$ tracer application plots. Six cores were composited for each plot. Due to difficulties locating some plots, the resampling sample sizes were $n=34$ plots (out of the original 36) at the SGS-LTER site and $n=38$ plots (out of the original 48) at the dryland cropping sites. Soil bulk densities were obtained from Burke et al. (1995) and Shaver et al. (2002) and from unpublished data by L. Sherrod (Supplemental Table S2).

Soils were air dried, sieved to $2 \mathrm{~mm}$, and fractionated into coarse and fine particulate organic matter fractions (CPOM and FPOM, respectively) according to the methods of Cambardella and Elliott (1992). The CPOM and FPOM fractions and bulk soils were analyzed for $\mathrm{N}$ and ${ }^{15} \mathrm{~N}$ on an elemental analyzer (Elementar Analysensysteme $\mathrm{GmbH}$ ) interfaced to a PDZ Europa 20-20 isotope ratio mass spectrometer (Sercon Ltd.) at the University of California-Davis Stable Isotope Facility.
We estimated percent ${ }^{15} \mathrm{~N}$ retention by scaling the ${ }^{15} \mathrm{~N}$ in 2003 soil samples up to a mass per area basis based on sample $\% \mathrm{~N}$ and soil bulk density (Robinson, 2001):

$$
\begin{aligned}
& \frac{\mathrm{g}^{15} \mathrm{~N}}{\mathrm{~g} \text { sample }}= \\
& \frac{\text { sample } \% \mathrm{~N}}{100} * \frac{\text { sample atom } \%-\text { nat abundance atom } \%}{\text { label atom } \%-\text { nat abundance atom } \%}
\end{aligned}
$$

where natural abundance (nat abundance) $=0.3663$ atom \%, and label $=78.2$ atom $\%$, and

$$
\begin{aligned}
& \frac{\mathrm{g} \text { fraction }{ }^{15} \mathrm{~N}}{\mathrm{~m}^{2}}= \\
& \frac{\mathrm{g}^{15} \mathrm{~N}}{\mathrm{~g} \text { fraction }} * \frac{\mathrm{g} \text { fraction }}{\text { g whole soil }} * \frac{\mathrm{g} \text { soil }}{\mathrm{m}^{3} \text { soil }} * \mathrm{~m} \text { soil depth increment }
\end{aligned}
$$

for POM fractions and

$$
\frac{\text { g soil }{ }^{15} \mathrm{~N}}{\mathrm{~m}^{2}}=\frac{\mathrm{g}^{15} \mathrm{~N}}{\mathrm{~g} \text { soil }} * \frac{\mathrm{g} \text { soil }}{\mathrm{m}^{3} \text { soil }} * \mathrm{~m} \text { soil depth increment }
$$

for whole soils, then divided the mass by $2 \mathrm{~g} \mathrm{~m}^{-2}$, which is the quantity of ${ }^{15} \mathrm{~N}$ that was applied in 1988 . Total POM ${ }^{15} \mathrm{~N}$ retention was equal to the sum of the two POM fractions' ${ }^{15} \mathrm{~N}$ retentions. Soil profile $(0-30 \mathrm{~cm}){ }^{15} \mathrm{~N}$ retention was equal to the sum of the two depth increments' ${ }^{15} \mathrm{~N}$ retentions.

To estimate an index of $\mathrm{N}$ retention in the same units as the $\mathrm{N}$ budget, we multiplied the $15-\mathrm{yr} \%{ }^{15} \mathrm{~N}$ retention of each site $x$ treatment combination by the mean annual total $\mathrm{N}$ inputs to that treatment at that site:

$$
\begin{aligned}
& 15-\mathrm{yr} \mathrm{N} \text { retention }= \\
& \quad{ }^{15} \mathrm{~N} \text { retention }{ }^{*} \text { mean annual } \mathrm{N} \text { inputs }
\end{aligned}
$$

This yielded an estimate of the 15 -yr retention of a given year's $\mathrm{N}$ inputs. We then estimated 15-yr $\mathrm{N}$ losses (to erosion, leaching, and trace gas emissions) as

$15-\mathrm{yr} \mathrm{N}$ losses $=$

mean annual total $\mathrm{N}$ inputs - mean annual $\mathrm{N}$ removals

-15 -yr $\mathrm{N}$ retention

Because these estimates represent the 15 -yr fate of a given year's $\mathrm{N}$ inputs and because ${ }^{15} \mathrm{~N}$ is more strongly retained than ${ }^{14} \mathrm{~N}$ due to discrimination against the heavy isotope by biological processes, these estimates are regarded as indices, rather than quantitative estimates, of soil $\mathrm{N}$ retention and loss.

Analyses of variance were used to assess differences in percent $\mathrm{N}$ retention among sites, treatments, soil depths, and POM fractions. All ANOVAs were implemented using the opensource statistical program $\mathrm{R}$, version 2.15.0 ( $\mathrm{R}$ Development Core Team, 2011) using $\operatorname{lme}()$ and anova() functions in the nlme package. Multiple comparisons were performed using Tukey's honestly significant difference (Hsu, 1996). Significant differences were assessed at $\alpha=0.05$.

For plots at SGS-LTER, soil depth-dependent differences were assessed with three-way ANOVAs comparing bulk soil 
$\mathrm{N}$, bulk soil ${ }^{15} \mathrm{~N}$ retention, POM N, and POM ${ }^{15} \mathrm{~N}$ retention among factor levels of the independent variables depth, grazing treatment, and topographic position as fixed effects, with toposequence included as a random effect. Two-way ANOVAs tested differences in 0 - to $30-\mathrm{cm}$ soil $\mathrm{N}$ pools and 0 - to $30-\mathrm{cm}^{15} \mathrm{~N}$ retention between grazing treatments and topographic positions (fixed effects) with toposequence as a random effect. To evaluate differences between the different POM fractions, three-way ANOVAs compared 0 - to $30-\mathrm{cm}$ POM N pools and 0 - to $30-\mathrm{cm}$ $P O M{ }^{15} \mathrm{~N}$ retention based on the independent variables POM fraction (fine vs. coarse), grazing treatment, and topographic position (fixed effects), with toposequence as a random effect.

At the cropped sites, soil depth-dependent differences were assessed with three-way ANOVAs comparing bulk soil N, bulk soil ${ }^{15} \mathrm{~N}$ retention, $\mathrm{POMN}$, and $\mathrm{POM}^{15} \mathrm{~N}$ retention among factor levels of the independent variables depth, cropping treatment, and site (fixed effects), with planting strip included as a random effect. Two-way ANOVAs tested differences in 0 - to $30-\mathrm{cm}$ bulk soil $\mathrm{N}$ pools and 0 - to $30-\mathrm{cm}$ bulk soil ${ }^{15} \mathrm{~N}$ retention between cropping treatments and sites (fixed effects), accounting for a planting strip random effect. Three-way ANOVAs compared 0to $30-\mathrm{cm}$ POM N pools and $0-$ to $30-\mathrm{cm} P O M{ }^{15} \mathrm{~N}$ retention based on the independent variables POM fraction, cropping treatment, and site as fixed effects, and planting strip as a random effect. Where there were no significant differences among crop treatments, plots from the three crop rotations were analyzed as one pooled "crop" treatment to simplify data presentation.

\section{Results}

Overall, cropland management practices had the strongest influence on long-term soil $\mathrm{N}$ retention. Grazing and topography had no significant effects on long-term $\mathrm{N}$ retention. Fifteen years after application, site-level mean 0 - to $30-\mathrm{cm}$ soil $\mathrm{N}$ retention varied from 40.9 to $47.8 \%$, whereas crop and grazing management treatment-level means varied from 18.8 to $93.8 \%$ (Table 1). Planted perennial grass systems retained a higher percentage of ${ }^{15} \mathrm{~N}$ than native grasslands, which exceeded the ${ }^{15} \mathrm{~N}$ retention of no-till crops. However, no-till crops retained the largest mass $\mathrm{N}$ due to the high quantities of $\mathrm{N}$ input to those systems (Fig. 1).
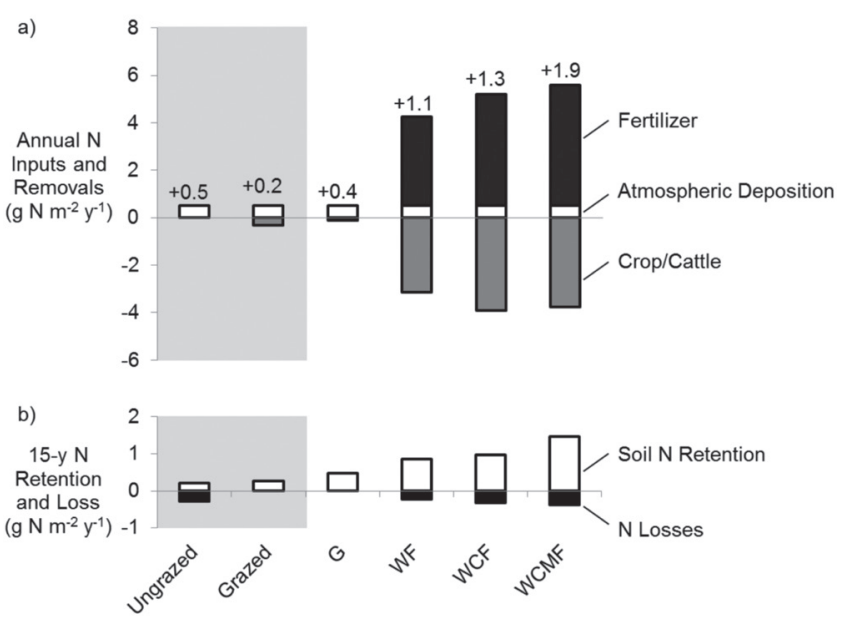

Fig. 1. (a) Nitrogen inputs (as fertilizer and atmospheric depositionpositive columns) and removals (in grain and stover or cattle production-negative columns) and the resulting $\mathrm{N}$ imbalance (i.e., the difference between inputs and removals, indicated by value above columns) under six agricultural management treatments in intact and cropped former shortgrass steppe of eastern Colorado. (b) Index of soil $\mathrm{N}$ retention $(15-\mathrm{yr} \% \mathrm{~N}$ retention treatment means $\times$ mean annual $\mathrm{N}$ inputs - positive columns) and $\mathrm{N}$ losses (i.e., the difference between soil $\mathbf{N}$ retention index and the net $\mathrm{N}$ imbalance, which is presumably lost from the system via erosion, leaching, and/or trace gas emissions-negative columns). Values in (a) represent means of 15 yr of annual input and removal data, and values in (b) represent the $15-y r$ fate of a given year's inputs. The Shortgrass Steppe-Long-Term Ecological Research experimental treatments (Ungrazed and Grazed intact grassland) are highlighted in the gray shaded box, and the dryland agriculture treatments (planted perennial grass [G], wheatfallow [WF], wheat-corn-fallow [WCF], and wheat-corn-millet-fallow [WCMF]) are displayed against a white background.

\section{Soil N Pools}

In general, surface 0 - to 10 -cm soils had larger bulk soil $\mathrm{N}$ pools (depth, $p=0.01$ for SGS-LTER and $p<0.0001$ for cropped sites) and retained more ${ }^{15} \mathrm{~N}$ (depth, $p<0.0001$ for SGS-LTER and for cropped sites) than the 10- to 30-cm soils (Tables 2 and 3). Surface soils also had higher POM ${ }^{15} \mathrm{~N}$ retention than deeper soils (depth, $p<0.0001$ for SGS-LTER; depth $\times$ site, $p=0.0001$ at cropped sites) (Tables 2 and 3 ). Fine POM-N pools $(0-30 \mathrm{~cm}$ ) were greater than CPOM-N pools (fraction, $p<0.0001$ for SGSLTER and for cropped sites) (Tables 4 and 5). At SGS-LTER, no factors affected CPOM or FPOM N pool size (no interactions

Table 1. Summary of $15-\mathrm{yr} 0$ - to $30-\mathrm{cm}$ bulk soil ${ }^{15} \mathrm{~N}$ retention by sites, topographic positions, and management treatments.

\begin{tabular}{|c|c|c|c|c|c|}
\hline \multirow{2}{*}{ Grouping variable } & \multirow{2}{*}{ Experiment } & \multirow{2}{*}{ Factor level } & \multicolumn{3}{|c|}{$0-30 \mathrm{~cm}$ soil ${ }^{15} \mathrm{~N}$ retention } \\
\hline & & & Mean & SE & $n$ \\
\hline & & & 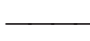 & 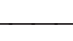 & \\
\hline \multirow[t]{3}{*}{ Site } & SGS-LTER $†$ & SGS-LTER & 47.8 & 3.05 & 27 \\
\hline & Dryland Ag & Stratton & 45.5 & 9.16 & 18 \\
\hline & Dryland Ag & Sterling & 40.9 & 7.91 & 16 \\
\hline \multirow[t]{2}{*}{ Topographic position } & SGS-LTER & ridge & 48.1 & 4.04 & 14 \\
\hline & SGS-LTER & swale & 47.5 & 4.77 & 13 \\
\hline \multirow[t]{6}{*}{ Management treatment } & SGS-LTER & grazed & 41.4 & 3.91 & 12 \\
\hline & SGS-LTER & ungrazed & 52.9 & 4.16 & 15 \\
\hline & Dryland Ag & planted perennial grass & 93.7 & 4.44 & 10 \\
\hline & Dryland Ag & wheat-fallow & 20.4 & 5.05 & 6 \\
\hline & Dryland Ag & wheat-corn-fallow & 18.8 & 3.16 & 8 \\
\hline & Dryland Ag & wheat-corn-millet-fallow & 26.3 & 4.00 & 10 \\
\hline
\end{tabular}

† Shortgrass Steppe Long-Term Ecological Research. 
on fraction) (Table 4). At the dryland cropping sites, treatment and site interactively affected CPOM and FPOM N pools, with significantly more FPOM than CPOM in the planted perennial grass treatment at the Sterling site (fraction $\times$ site $\times$ treatment; $p$ $<0.01$ ) (Table 5).

\section{Topographic and Site Controls of ${ }^{15} \mathrm{~N}$ Retention}

Topographic position, as a proxy for soil texture, had no effect on ${ }^{15} \mathrm{~N}$ retention, whereas site, as a proxy for climate, had minor effects. There were no differences in $\mathrm{N}$ pools or $\mathrm{N}$ retention between summits and toeslopes at the SGS-LTER site (Tables 2 and 4). For the cropped systems, the southern Stratton site retained more ${ }^{15} \mathrm{~N}$ in 0 - to $10-\mathrm{cm}$ soils under planted perennial grass than did Sterling (depth $\times$ treatment $\times$ site; $p<0.01$ ) (Table 3; Fig. 2b), but there was no significant difference in mean total $(30 \mathrm{~cm})$ profile bulk soil $\mathrm{N}$ retention between the two agricultural sites (Table 5; Fig. 2a). There was no difference in 0to $30-\mathrm{cm} \mathrm{N}$ retention between POM fractions at the SGS-LTER site (Table 4), whereas FPOM fractions retained more ${ }^{15} \mathrm{~N}$ than
$\mathrm{CPOM}$ at the agricultural sites (Fraction $p<0.0001$ ) (Table 5; Fig. 2a).

\section{Management Effects on ${ }^{15} \mathrm{~N}$ Retention}

At the SGS-LTER site, there was no significant effect of grazing on $\mathrm{N}$ pools or ${ }^{15} \mathrm{~N}$ retention (Table 4). Ungrazed shortgrass steppe averaged $52.9 \%( \pm 4.16 \mathrm{SE}) \mathrm{N}$ retention, whereas grazed shortgrass steppe averaged $41.4 \%$ ( $\pm 3.91 \mathrm{SE})$.

At the agricultural sites, 0 - to $30-\mathrm{cm} \mathrm{N}$ pools differed among treatments, with the WCMF treatment having greater soil $\mathrm{N}$ than the other three treatments (treatment, $p=0.051$ ) (Table 5). This effect was driven by a high WCMF N pool in 0 - to 10 - $\mathrm{cm}$ soils at the Sterling site, which far exceeded that of any other treatment or site at that depth (Fig. 3). There were no differences in soil $\mathrm{N}$ retention among cropping intensities, but there were strong differences between no-till crops and planted perennial grass: at both cropped sites, planted grass retained more ${ }^{15} \mathrm{~N}$ throughout the 0 - to $30-\mathrm{cm}$ soil profile $(93.3 \% \pm 2.85 \mathrm{SE})$ than did any of the no-till cropped treatments ( $<30 \%$; treatment, $p<0.0001$ ) (Table 5; Fig. 2a). When the plots from the three crop rotations

Table 2. Results of three-way ANOVAs for bulk soil $\mathrm{N}$ pools and ${ }^{15} \mathrm{~N}$ retention and total (coarse + fine) particulate organic matter $\mathrm{N}$ pools and $\mathrm{N}$ retention at the Shortgrass Steppe Long-Term Ecological Research site. There were no significant interaction terms.

\begin{tabular}{|c|c|c|c|c|c|c|c|}
\hline \multirow{2}{*}{ Response variable } & \multirow{2}{*}{ Independent variable } & \multicolumn{3}{|c|}{ N pool } & \multicolumn{3}{|c|}{${ }^{15} \mathrm{~N}$ retention } \\
\hline & & df & $F$ & $p$ Value & df & $\mathrm{F}$ & $p$ Value \\
\hline \multirow[t]{4}{*}{ Bulk soil $\mathrm{N}$} & depth & 1 & 7.06 & $0.010^{*}$ & 1 & 57.3 & $<0.0001^{*}$ \\
\hline & treatment & 1 & 0.019 & 0.898 & 1 & 1.59 & 0.276 \\
\hline & topographic position & 1 & 1.37 & 0.248 & 1 & 0.197 & 0.659 \\
\hline & residuals & 58 & & & 58 & & \\
\hline \multirow[t]{4}{*}{ Total POM+ N } & depth & 1 & 0.106 & 0.746 & 1 & 51.7 & $<0.0001^{*}$ \\
\hline & treatment & 1 & 0.115 & 0.752 & 1 & 3.46 & 0.136 \\
\hline & topographic position & 1 & 0.799 & 0.375 & 1 & 0.401 & 0.529 \\
\hline & residuals & 64 & & & 64 & & \\
\hline
\end{tabular}

* Significant at the 0.05 probability level.

† Particulate organic matter.

Table 3. Results of three-way ANOVAs for bulk soil N pools and ${ }^{15} \mathrm{~N}$ retention and total (coarse + fine) particulate organic matter $\mathrm{N}$ pools and ${ }^{15} \mathrm{~N}$ retention at dryland cropping sites.

\begin{tabular}{|c|c|c|c|c|c|c|c|}
\hline \multirow{2}{*}{ Response variable } & \multirow{2}{*}{ Independent variable } & \multicolumn{3}{|c|}{$\mathrm{N}$ pool } & \multicolumn{3}{|c|}{${ }^{15} \mathrm{~N}$ retention } \\
\hline & & df & $F$ & $p$ Value & df & $\mathbf{F}$ & $p$ Value \\
\hline \multirow[t]{8}{*}{ Bulk soil N } & depth & 1 & 85.7 & $<0.0001^{*}$ & 1 & 41.9 & $<0.0001^{*}$ \\
\hline & treatment & 3 & 3.47 & $0.024^{*}$ & 3 & 40.5 & $<0.0001^{*}$ \\
\hline & site & 1 & 18.9 & $0.0001^{*}$ & 1 & 0.103 & 0.744 \\
\hline & depth $\times$ treatment & 3 & 0.554 & 0.648 & 3 & 11.5 & $<0.0001^{*}$ \\
\hline & depth $\times$ site & 1 & 1.32 & 0.256 & 1 & 4.02 & 0.051 \\
\hline & treatment $\times$ site & 3 & 2.94 & $0.043 *$ & 3 & 0.868 & 0.464 \\
\hline & depth $\times$ treatment $\times$ site & 3 & 4.41 & $0.008^{*}$ & 3 & 4.68 & $0.006^{*}$ \\
\hline & residuals & 56 & & & 56 & & \\
\hline \multirow[t]{8}{*}{ Total POM+ N } & depth & 1 & 22.9 & $<0.0001^{*}$ & 1 & 29.0 & $<0.0001^{*}$ \\
\hline & treatment & 3 & 0.755 & 0.525 & 3 & 33.4 & $<0.0001^{*}$ \\
\hline & site & 1 & 30.1 & $<0.0001^{*}$ & 1 & 2.45 & 0.123 \\
\hline & depth $\times$ treatment & 3 & 0.730 & 0.539 & & & $-\ddagger$ \\
\hline & depth $\times$ site & 1 & 0.732 & 0.396 & & 8.61 & $0.0001^{*}$ \\
\hline & treatment $\times$ site & 3 & 0.899 & 0.448 & & & - \\
\hline & depth $\times$ treatment $\times$ site & 3 & 4.88 & $0.005^{*}$ & & & - \\
\hline & residuals & 60 & & & 67 & & \\
\hline
\end{tabular}

* Significant at the 0.05 probability level.

† Particulate organic matter.

キ Nonsignificant interaction terms. 
were analyzed as one pooled "crop" treatment, planted grass surface 0 - to $10-\mathrm{cm}$ soils retained significantly more $\mathrm{N}$ than crop surface soils (Fig. 2b). At Sterling, planted grass 10- to 30-cm N retention was significantly higher than $10-$ to $30-\mathrm{cm}$ crop soils; at Stratton, 10- to 30-cm planted grass soil $\mathrm{N}$ retention did not differ from that of crop soils (depth $\times$ treatment $\times$ site; $p<0.01$ ) (Table 3; Fig. 2b).

\section{Nitrogen Budgets of Treatments}

Nitrogen budgets for the management treatments of the two experiments showed lower $\mathrm{N}$ inputs to and $\mathrm{N}$ exports from grassland treatments, both native and planted, compared with cropped treatments (Fig. 1a). Nitrogen inputs increased with increasing cropping intensity. Nitrogen removals also increased, but to a lesser extent. As a result, the net positive imbalance between inputs and removals increased with increasing cropping intensity (Fig. 1a). In partitioning that imbalance into estimates of soil $\mathrm{N}$ retention and $\mathrm{N}$ loss, estimates of mass $\mathrm{N}$ retained increased with $\mathrm{N}$ inputs to a greater extent than did estimated $\mathrm{N}$ losses to trace gas fluxes, erosion, or leaching (Fig. 1b).

\section{Discussion}

Data from this unique long-term study show that cropping reduced percent soil $\mathrm{N}$ retention relative to intact grasslands. However, our $\mathrm{N}$ budget suggests that intensive no-till cropping increased the mass of $\mathrm{N}$ retained in soil due to the larger magnitude of $\mathrm{N}$ inputs. As a result, we find that intensive no-till cropping does not have large impacts on total $\mathrm{N}$ losses in dryland areas such as eastern Colorado. This is an especially surprising result given the greater $\mathrm{N}$ inputs and biomass production in these cropped systems compared with intact native grasslands.

\section{Ecological Implications}

Overall, long-term $\mathrm{N}$ retention in these current or former shortgrass steppe ecosystems was relatively high compared with similar ecosystems (Tables 1 and 6). Our study is unique in the duration of the experiment (Table 6) and the representation of regional climate and diverse management practices. A metaanalysis of $217^{15} \mathrm{~N}$ tracer studies in grain cropping systems found that only $58 \%$ of studies measured soils and only $33 \%$ monitored beyond one growing season; only five studies sampled soils at 1 yr or more after tracer application (Gardner and Drinkwater, 2009). That meta-analysis found $\mathrm{N}$ retention in grain cropping systems (plant or plant+soil) to vary from 52 to $74 \%$ of added $\mathrm{N}$ but argued that the numbers were of limited use because the short time span missed winter $\mathrm{N}$ losses and likely resulted in overestimates of $\mathrm{N}$ retention (Gardner and Drinkwater, 2009). A recent long-term study recovered 12 to $15 \%$ of fertilizer $\mathrm{N}$ in soils under conventionally tilled sugar beet-winter wheat rotations after $25 \mathrm{yr}$ (Sebilo et al., 2013). Our estimates of 19 to $26 \% \mathrm{~N}$ retention in crop soils after $15 \mathrm{yr}$ are slightly higher but comparable. For intact grasslands, a meta-analysis of ${ }^{15} \mathrm{~N}$ tracer studies found grassland organic + mineral soils to retain $\sim 20 \%$ of

Table 4. Results of two-way ANOVAs for 0 - to $30-\mathrm{cm}$ bulk soil $\mathrm{N}$ pools and ${ }^{15} \mathrm{~N}$ retention and three-way ANOVAs for 0 - to $30-\mathrm{cm}$ particulate organic matter fraction $\mathrm{N}$ pools and ${ }^{15} \mathrm{~N}$ retention at the Shortgrass Steppe Long-Term Ecological Research site. There were no significant interaction terms.

\begin{tabular}{|c|c|c|c|c|c|c|c|}
\hline \multirow{2}{*}{ Response variable } & \multirow{2}{*}{ Independent variable } & \multicolumn{3}{|c|}{ N pool } & \multicolumn{3}{|c|}{${ }^{15} \mathrm{~N}$ retention } \\
\hline & & df & $\mathrm{F}$ & $p$ Value & df & $\mathrm{F}$ & $p$ Value \\
\hline \multirow[t]{3}{*}{$0-30 \mathrm{~cm}$ bulk soil $\mathrm{N}$} & treatment & 1 & 0.075 & 0.798 & 1 & 3.41 & 0.139 \\
\hline & topographic position & 1 & 1.81 & 0.192 & 1 & 0.012 & 0.912 \\
\hline & residuals & 24 & & & 24 & & \\
\hline \multirow[t]{4}{*}{$0-30 \mathrm{~cm}$ POM N } & fraction & 1 & 121 & $<0.0001^{*}$ & 1 & 0.060 & 0.808 \\
\hline & treatment & 1 & 0.119 & 0.748 & 1 & 3.58 & 0.131 \\
\hline & topographic position & 1 & 0.866 & 0.356 & 1 & 1.05 & 0.309 \\
\hline & residuals & 64 & & & 64 & & \\
\hline
\end{tabular}

* Significant at the 0.05 probability level.

Table 5. Results of two-way ANOVAs for 0 - to $30-\mathrm{cm}$ bulk soil $\mathrm{N}$ pools and ${ }^{15} \mathrm{~N}$ retention and three-way ANOVAs for 0 - to $30-\mathrm{cm}$ particulate organic matter fraction $\mathrm{N}$ pools and ${ }^{15} \mathrm{~N}$ retention at dryland cropping sites.

\begin{tabular}{|c|c|c|c|c|c|c|c|}
\hline \multirow{2}{*}{ Response variable } & \multirow{2}{*}{ Independent variable } & \multicolumn{3}{|c|}{$\mathrm{N}$ pool } & \multicolumn{3}{|c|}{${ }^{15} \mathrm{~N}$ retention } \\
\hline & & df & $\mathrm{F}$ & $p$ Value & df & $\mathrm{F}$ & $p$ Value \\
\hline \multirow[t]{3}{*}{$0-30 \mathrm{~cm}$ bulk soil $\mathrm{N}$} & treatment & 3 & 3.10 & 0.051 & 3 & 77.3 & $<0.0001^{*}$ \\
\hline & site & 1 & 18.6 & $<0.001^{*}$ & 1 & 1.13 & 0.300 \\
\hline & residuals & 29 & & & 29 & & \\
\hline \multirow[t]{8}{*}{$0-30 \mathrm{~cm}$ POM+ N } & POM fraction & 1 & 725 & $<0.0001^{*}$ & 1 & 19.9 & $<0.0001^{*}$ \\
\hline & treatment & 3 & 3.64 & $0.020^{*}$ & 3 & 127 & $<0.0001^{*}$ \\
\hline & site & 1 & 47.4 & $<0.0001^{*}$ & 1 & 5.20 & $0.027^{*}$ \\
\hline & POM fraction $\times$ treatment & 3 & 6.94 & $<0.001^{*}$ & & & $-\ddagger$ \\
\hline & POM fraction $\times$ site & 1 & 23.4 & $<0.0001^{*}$ & 1 & 4.48 & $0.038^{*}$ \\
\hline & treatment $\times$ site & 3 & 2.59 & 0.065 & & & - \\
\hline & $\begin{array}{l}\text { POM fraction } \times \text { treatment } \\
\times \text { site }\end{array}$ & 3 & 4.83 & $0.006^{*}$ & & & - \\
\hline & residuals & 54 & & & 63 & & \\
\hline
\end{tabular}

* Significant at the 0.05 probability level.

† Particulate organic matter.

‡ Nonsignificant interaction terms. 

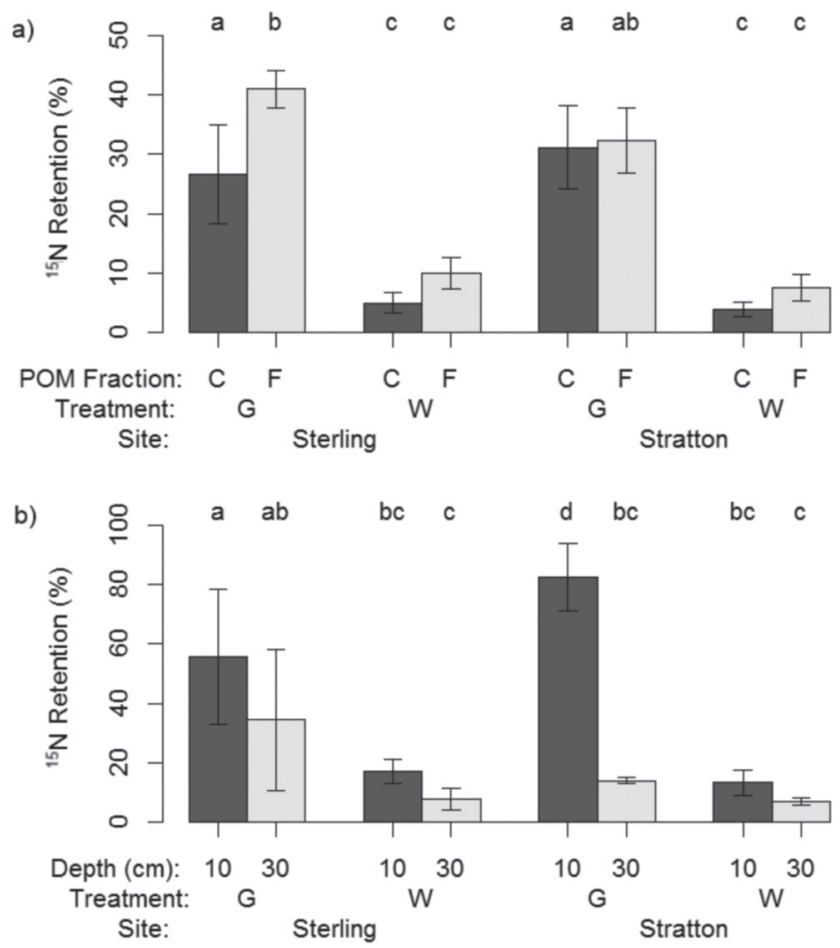

Fig. 2. Soil $\mathrm{N}$ retention (as percent of added ${ }^{15} \mathrm{~N}$ recovered after $15 \mathrm{yr}$ ) in dryland cropping soils at two sites (Sterling and Stratton) under two categories of management (G: planted perennial grasses; W: wheat production, with three cropping intensities pooled) in (a) two particulate organic matter (POM) fractions (coarse $[C]$ vs. fine $[F]$ ) of 0 to $30 \mathrm{~cm}$ soil and (b) bulk soils at two soil depths $(0-10 \mathrm{~cm}$ and $10-30$ $\mathrm{cm}$ ). Error bars indicate $95 \%$ confidence intervals. Lowercase letters indicate significant differences at $\alpha=0.05$ as assessed by Tukey's honestly significant difference method. Columns with the same letter are not significantly different.

tracer $\mathrm{N}$ after 3 to $18 \mathrm{mo}$ (Table 2) (Templer et al., 2012). A 4-yr study at a shortgrass steppe site near the SGS-LTER site found $45 \%$ soil $\mathrm{N}$ retention, which is very similar to values reported in this study (Clark, 1977).

We expected higher $\mathrm{N}$ retention in the higher-intensity crop treatment because we expected greater biomass production and residue return to cause larger SOM pools and greater $\mathrm{N}$ immobilization. However, we found no differences in $\mathrm{N}$ retention among cropping intensities and found greater soil $\mathrm{N}$ pools at only one site in the most intense treatment. We found cropped soil $\mathrm{N}$ retention $(<30 \%)$ to be low relative to less productive intact grass treatments $(>40 \%)$ (Table 1; Fig. 2a). These results are similar to other published work at these dryland no-till agriculture sites, which observed little change in 0- to

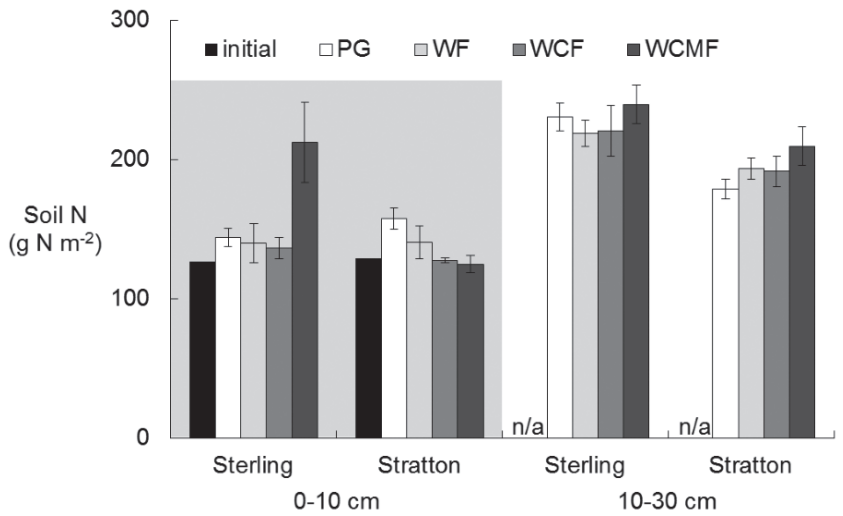

Fig. 3. Soil $N$ pools $( \pm 1 \mathrm{SE})$ at two depths $(0-10 \mathrm{~cm}$, left, gray background; 10-30 cm, right, white background) at two sites (Sterling and Stratton) under four cropping intensity treatments (white and gray bars; wheat-fallow [WF], wheat-corn-fallow [WCF], wheatcorn-millet-fallow [WCMF]) in 2003. Initial 1989 0- to 10-cm site-level means (black bars, no uncertainty estimates) taken from Wood et al. (1990). n/a, no initial data available for the $10-$ to $30-\mathrm{cm}$ depth.

10-cm soil organic carbon or soil organic $\mathrm{N}$ over the first decade after adoption of no-till practices, with no differences among the various cropping intensities (Ortega et al., 2005). Apparently, rates of biomass production and residue return, though higher in the WCMF than WF treatment, were not the important factor determining $\mathrm{N}$ retention.

It may be that biomass $\mathrm{N}$ removals are the important regulator of $\mathrm{N}$ retention and loss in these semiarid systems. The unfertilized, planted perennial grass system had the highest percent $\mathrm{N}$ retention of all treatments in our study. An important driver of this high $\mathrm{N}$ retention may be that the planted perennial grass was only occasionally harvested for hay ( 3 out of $15 \mathrm{yr}$ ), resulting in a low mean annual $\mathrm{N}$ removal rate (Fig. 1a). The treatments with highest $\mathrm{N}$ removal rates had the lowest percent soil $\mathrm{N}$ retention. The ungrazed intact grassland ecosystem with the lowest $\mathrm{N}$ removal rates had significantly higher soil POM $\mathrm{N}$ retention than the grazed intact grassland. These results suggest that the rate of biomass $\mathrm{N}$ removal from the ecosystem is an important control on soil $\mathrm{N}$ retention in managed semiarid ecosystems.

Topography affects soil moisture and soil texture, two of the primary controls on SOM pools, and turnover in the intact shortgrass steppe ecosystem (Burke et al., 1999; Hook and Burke, 1995; Mosier et al., 1996; Schimel et al., 1985; Schimel et al., 1986). Previous studies of shorter duration have shown differences in $\mathrm{N}$ retention between topographic positions

Table 6. Grassland and crop soil N retention values from the literature.

\begin{tabular}{|c|c|c|c|}
\hline Reference & Ecosystem component & $\mathrm{N}$ retention & Study duration \\
\hline & & $\%$ & \\
\hline Clark et al., $1977 \dagger$ & USA shortgrass steppe soil & 45 & $4 \mathrm{yr}$ \\
\hline Curtis et al., 2005† & UK moorland organic horizon & $0-4$ & $1 \mathrm{yr}$ \\
\hline Hart et al., 1993 & California annual grassland soil + litter + roots & 67 & $1 \mathrm{yr}$ \\
\hline Hooper and Vitousek, 1997† & California serpentine grassland soil & $<15$ & 1 growing season \\
\hline Providoli et al., $2006+$ & Swiss mountain meadow soil + roots & $<15$ & $1 \mathrm{yr}$ \\
\hline Templer et al., 2012 & global grassland soil & 20 & $<18 \mathrm{mo}$ \\
\hline Sebilo et al., 2013 & French grain cropland soil & $12-15$ & $28 \mathrm{yr}$ \\
\hline Gardner and Drinkwater, 2009 & global grain cropland soil & 29 & 1 growing season \\
\hline
\end{tabular}

† Included in Templer et al., 2012. 
(Delgado et al., 1996), but we found no differences in $\mathrm{N}$ retention between topographic positions or POM fractions on native grassland after $15 \mathrm{yr}$, indicating that the environmental factors that control $\mathrm{N}$ pools and shorter-term $\mathrm{N}$ dynamics may not regulate longer-term $\mathrm{N}$ retention.

For grasslands and croplands more generally, meta-analyses have found $\mathrm{N}$ inputs and climate to be strong controls of $\mathrm{N}$ retention. A threshold value of $4.6 \mathrm{~g} \mathrm{~N} \mathrm{~m}^{-2} \mathrm{yr}^{-1}$ has been reported for grassland $\mathrm{N}$ additions, above which $\mathrm{N}$ additions caused reductions in ecosystem $\mathrm{N}$ retention (Templer et al., 2012). Soil $\mathrm{N}$ retention was also observed to decrease with increasing fertilization rates in cropped systems (Gardner and Drinkwater, 2009). The $\mathrm{N}$ addition rates of cropped sites in this study are near or above the $4.6 \mathrm{~g} \mathrm{~N} \mathrm{~m}^{-2} \mathrm{yr}^{-1}$ threshold (4.3-5.6 $\mathrm{g} \mathrm{N} \mathrm{m}^{-2}$ $\left.\mathrm{yr}^{-1}\right)$, whereas the three perennial grass treatments are below it ( $\mathrm{N}$ deposition $\sim 0.5 \mathrm{~g} \mathrm{~N} \mathrm{~m}^{-2} \mathrm{yr}^{-1}$ ). However, soil $\mathrm{N}$ retention in our grassland sites (45-93\%) and our agricultural sites ( 20\%) are higher than in other systems (Tables 1 and 6). Furthermore, percent $\mathrm{N}$ retention did not change as fertilizer $\mathrm{N}$ additions increased with increasing cropping intensity; thus, the mass of $\mathrm{N}$ retained increased with increasing cropping intensity, limiting the $\mathrm{N}$ available to be lost to leaching, erosion, or trace gas flux. Soil $\mathrm{N}$ retention has been observed to increase, and plant ${ }^{15} \mathrm{~N}$ removals to decrease, as the ratio of precipitation to evaporation decreases (Gardner and Drinkwater, 2009). The semiarid climate of these sites is likely a major factor driving high soil $\mathrm{N}$ retention and low $\mathrm{N}$ loss relative to other grassland and cropland systems.

\section{Management Implications}

To compare $\mathrm{N}$ use by dryland no-till crops with other crop systems, we estimated the net $\mathrm{N}$ imbalance between inputs and removals and indices of the mass of $\mathrm{N}$ retained versus lost for the different treatments. Averaged across all no-till cropped treatments and sites, the imbalance between fertilizer inputs and crop removals was an excess of $1.4 \mathrm{~g} \mathrm{~N} \mathrm{~m}^{-2} \mathrm{yr}^{-1}$ input to the system. Estimates of $\mathrm{N}$ losses after accounting for soil $\mathrm{N}$ retention in the three cropped systems were 0.07 to $0.10 \mathrm{~g} \mathrm{~N}$ per every $1 \mathrm{~g} \mathrm{~N}$ harvested in crops. This amounts to $\mathrm{N}$ use efficiency (NUE) (where NUE $=$ crop $\mathrm{N} / \mathrm{N}$ fertilization) estimates of 0.7 to $0.8 \mathrm{~g} \mathrm{~N}$ harvested per g $\mathrm{N}$ added. For comparison, in conventional wheat and corn production systems in subhumid central Kansas, assumed to be in steady state regarding soil $\mathrm{N}$ pools, an approximately $+2.5 \mathrm{~g} \mathrm{~N} \mathrm{~m}^{-2} \mathrm{yr}^{-1}$ imbalance between $\mathrm{N}$ inputs and crop removals (Burke et al., 2002) amounted to 0.15 to $0.5 \mathrm{~g} \mathrm{~N}$ lost for every $1 \mathrm{~g} \mathrm{~N}$ of crop removal (NUE: $0.5-0.9 \mathrm{~g}$ $\mathrm{N}$ harvested per $\mathrm{g} \mathrm{N}$ added).

Fertilization and crop production rates in central Kansas are an order of magnitude higher than in eastern Colorado, and the subhumid systems lose 1.5 to 7 times more $N$ per unit crop produced than the semiarid dryland systems. The relatively low $\mathrm{N}$ inputs, removals, and $\mathrm{N}$ imbalance in dryland wheat farming and the higher soil $\mathrm{N}$ retention associated with the semiarid climate likely explain why the wheat-dominated semiarid western portions of the Mississippi River basin, despite covering a large area, are not major contributors to Mississippi riverine $\mathrm{N}$ export and the Gulf of Mexico dead zone (Burkart and James, 1999; Goolsby et al., 2000; Robertson and Saad, 2013).

In untilled semiarid systems, more intensive management can increase the amount of protein or crop $\mathrm{N}$ that is harvested without greatly increasing $\mathrm{N}$ losses to erosion, leaching, or trace gas emissions. Although percent soil $\mathrm{N}$ retention decreased with increased management intensity from intact grasslands to intensively cropped systems, the cropped systems retained large amounts of $\mathrm{N}$ on a mass basis over $15 \mathrm{yr}$, more than did the perennial grass systems, due to much higher $\mathrm{N}$ inputs. The mass of $\mathrm{N}$ retained in soil increased sufficiently with increasing inputs that the estimates of $\mathrm{N}$ losses over $15 \mathrm{yr}$ were comparably low among intact and cropped systems (Fig. 1). Crop $\mathrm{N}$ loss estimates were greater than the zero losses estimated for grazed and planted grassland but comparable to ungrazed grassland. The large increase in $\mathrm{N}$ inputs and $\mathrm{N}$ removals and greater commodity production of the most intense cropping system (WCMF) did not appear to adversely affect soil $\mathrm{N}$ pools or $\mathrm{N}$ retention compared with less intense cropping (WCF, WF) and did not appear to increase $\mathrm{N}$ losses compared with ungrazed perennial grass systems.

Global food and fiber production has been responsible for the conversion of $70 \%$ of the world's grasslands and $50 \%$ of the world's savannas to cropland (Foley et al., 2011). Continuing to meet the food demands of a growing population will require increasing production from managed lands, particularly from areas that are currently underproducing relative to their potential (Foley et al., 2011). In the semiarid western United States, food production options are largely limited to livestock grazing or dryland wheat farming. Adoption of practices such as no-till, increased cropping intensity, and use of cover crops has been shown to increase water efficiency and agronomic yield (Matson et al., 1997). Based on past and current research, it appears that at the decadal timescale, these practices can be used in this semiarid region without detrimental effects on soil organic matter pools or enhanced $\mathrm{N}$ losses.

\section{Acknowledgments}

This paper is based on two long-term research projects supported by many grants and institutions. The initial experiments on no-till cropping systems and ${ }^{15} \mathrm{~N}$ labeling were funded by the National Science Foundation (BSR-8605191) and the Colorado State University Experiment Station. The long-term ${ }^{15} \mathrm{~N}$ study on the shortgrass steppe was funded by the National Science Foundation Shortgrass Steppe LongTerm Ecological Research Project (BSR-8612105, DEB-0217631). Part of the research was carried out at the Jet Propulsion Laboratory, California Institute of Technology, under a contract with the National Aeronautics and Space Administration. Copyright 2013 California Institute of Technology. Government sponsorship acknowledged. All projects represented close collaborations with the USDA Agricultural Research Service. A multitude of field technicians from Colorado State University assisted with field and lab work.

\section{References}

Barrett, J.E., and I.C. Burke. 2002. Nitrogen retention in semiarid ecosystems across a soil organic-matter gradient. Ecol. Appl. 12:878-890. doi:10.1890/1051-0761(2002)012[0878:NRISEA]2.0.CO;2

Bement, R.E. 1969. A stocking-rate guide for beef production on blue-grama range. J. Range Manage. 22:83-86. doi:10.2307/3896186

Bonfil, D.J., I. Mufradi, S. Klitman, and S. Asido. 1999. Wheat grain yield and soil profile water distribution in a no-till arid environment. Agron. J. 91:368-373. doi:10.2134/agronj1999.00021962009100030003x

Burkart, M.R., and D.E. James. 1999. Agricultural-nitrogen contributions to hypoxia in the Gulf of Mexico. J. Environ. Qual. 28:850-859. doi:10.2134/ jeq1999.00472425002800030016x

Burke, I.C., E.T. Elliott, and C.V.Cole. 1995. Influence of macroclimate, landscape position, and management on soil organic matter in agroecosystems. Ecol. Appl. 5:124-131. doi:10.2307/1942057 
Burke, I.C., W.K. Lauenroth, G. Cunfer, J.E. Barrett, A. Mosier, and P. Lowe. 2002. Nitrogen in the central grasslands region of the United States. Bioscience 52:813-823. doi:10.1641/0006-3568(2002)052[0813:NITC GR]2.0.CO;2

Burke, I.C., W.K. Lauenroth, R. Riggle, P. Brannen, B. Madigan, and S. Beard. 1999. Spatial variability of soil properties in the shortgrass steppe: The relative importance of topography, grazing, microsite, and plant species in controlling spatial patterns. Ecosystems 2:422-438. doi:10.1007/ s100219900091

Burke, I.C., A.R. Mosier, P.B. Hook, D.G. Milchunas, J.E. Barrett, M.A. Vinton, et al. 2008. Soil organic matter and nutrient dynamics of shortgrass steppe ecosystems. In: W.K. Lauenroth and I.C. Burke, editors, Ecology of the shortgrass steppe: A long term perspective. Oxford Univ. Press, New York. p. 306-341.

Burke, I.C., C.M. Yonker, W.J. Parton, C.V. Cole, K. Flach, and D.S. Schimel. 1989. Texture, climate, and cultivation effects on soil organic matter content in U.S. grassland soils. Soil Sci. Soc. Am. J. 53:800-805. doi:10.2136/sssaj1989.03615995005300030029x

Cambardella, C.A., and E.T. Elliott. 1992. Particulate soil organic-matter changes across a grassland cultivation sequence. Soil Sci. Soc. Am. J. 56:777-783. doi:10.2136/sssaj1992.03615995005600030017x

Clark, F.E. 1977. Internal cycling of nitrogen in shortgrass prairie. Ecology 58:1322-1333. doi: 10.2307/1935084

Curtis, C.J., B.A. Emmett, H. Grant, M. Kernan, B. Reynolds, and E. Shilland. 2005. Nitrogen saturation in UK moorlands: The critical role of bryophytes and lichens in determining retention of atmospheric $\mathrm{N}$ deposition. J. Appl. Ecol. 42:507-517. doi:10.1111/j.1365-2664.2005.01029.x

Delgado, J.A., A.R. Mosier, D.W. Valentine, D.S. Schimel, and W.J. Parton. 1996. Long term $15 \mathrm{~N}$ studies in a catena of the shortgrass steppe. Biogeochemistry 32:41-52. doi:10.1007/BF00001531

Evans, S.D., G.A. Peterson, D.G. Westfall, and E. McGee. 1994. Nitrate leaching in dryland agroecosystems as influenced by soil and climate gradients. J. Environ. Qual. 23:999-1005. doi:10.2134/ jeq1994.00472425002300050021x

Evans, S.E., I.C. Burke, and W.K. Lauenroth. 2011. Controls on soil organic carbon and nitrogen in Inner Mongolia, China: A cross-continental comparison of temperate grasslands. Global Biogeochem. Cycles 25:GB3006. doi:10.1029/2010GB003945

Foley, J.A., N. Ramankutty, K.A. Brauman, E.S. Cassidy, J.S. Gerber, M. Johnston, et al. 2011. Solutions for a cultivated planet. Nature 478:337342. doi: $10.1038 /$ nature 10452

Gardner, J.B., and L.E. Drinkwater. 2009. The fate of nitrogen in grain cropping systems: A meta-analysis of $15 \mathrm{~N}$ field experiments. Ecol. Appl. 19:21672184. doi:10.1890/08-1122.1

Goolsby, D.A., W.A. Battaglin, B.T. Aulenbach, and R.P. Hooper. 2000. Nitrogen flux and sources in the Mississippi River Basin. Sci. Total Environ. 248:7586. doi:10.1016/S0048-9697(99)00532-X

Hart, S.C., M.K. Firestone, E.A. Paul, and J.L. Smith. 1993. Flow and fate of soil nitrogen in an annual grassland and a young mixed-conifer forest. Soil Biol. Biochem. 25:431-442. doi:10.1016/0038-0717(93)90068-M

Hatfield, J.L., T.J. Sauer, and J.H. Prueger. 2001. Managing soils to achieve greater water use efficiency. Agron. J. 93:271-280. doi:10.2134/ agronj2001.932271x

Hook, P.B., and I.C. Burke. 1995. Evaluation of methods for estimating net nitrogen mineralization in a semiarid grassland. Soil Sci. Soc. Am. J. 59:831-837. doi:10.2136/sssaj1995.03615995005900030028x

Hooper, D.U., and P.M. Vitousek. 1997. The effects of plant composition and diversity on ecosystem processes. Science 277:1302-1305. doi:10.1126/ science.277.5330.1302

Hsu, J.C. 1996. Multiple comparisons: Theory and methods. Chapman \& Hall, London, UK.

Lauenroth, W.K., and I.C. Burke, editors. 2008. Ecology of the shortgrass steppe: A long term perspective. Oxford Univ. Press, New York.

Matson, P.A., W.J. Parton, A.G. Power, and M.J. Swift. 1997. Agricultural intensification and ecosystem properties. Science 277:504-509. doi:10.1126/science.277.5325.504

McGee, E.A., G.A. Peterson, and D.G. Westfall. 1997. Water storage efficiency in no-till dryland cropping systems. J. Soil Water Conserv. 52:131-136.

Milchunas, D.G., W.K. Lauenroth, and I.C. Burke. 1998. Livestock grazing: Animal and plant biodiversity of shortgrass steppe and the relationship to ecosystem function. Oikos 83:65-74. doi:10.2307/3546547

Milchunas, D.G., W.K. Lauenroth, I.C. Burke, and J.K. Detling. 2008. Effects of Grazing on Vegetation. In: W.K. Lauenroth and I.C. Burke, editors, Ecology of the shortgrass steppe: A long-term perspective. Oxford Univ. Press, New York.
Miller, A.J., R. Amundson, I.C. Burke, and C. Yonker. 2004. The effect of climate and cultivation on soil organic C and N. Biogeochemistry 67:57-72. doi:10.1023/B:BIOG.0000015302.16640.a5

Mosier, A.R., W.J. Parton, D.W. Valentine, D.S. Ojima, D.S. Schimel, and J.A. Delgado. 1996. CH4 and N2O fluxes in the Colorado shortgrass steppe: 1. Impact of landscape and nitrogen addition. Global Biogeochem. Cycles 10:387-399. doi:10.1029/96GB01454

Ortega, R.A., D.G. Westfall, and G.A. Peterson. 2005. Climatic gradient, cropping system, and crop residue impacts on carbon and nitrogen mineralization in no-till soils. Commun. Soil Sci. Plant Anal. 36:. doi:10.1080/00103620500306064

Paruelo, J.M., E.G. Jobbagy, O.E. Sala, W.K. Lauenroth, and I.C. Burke. 1998. Functional and structural convergence of temperate grassland and shrubland ecosystems. Ecol. Appl. 8:194-206. doi:10.1890/1051-0761(1998)008[0194:FASCOT]2.0.CO;2

Peterson, G.A., and D.G. Westfall. 2004. Managing precipitation use in sustainable dryland agroecosystems. Ann. Appl. Biol. 144. doi:10.1111/j.1744-7348.2004.tb00326.x

Peterson, G.A., D.G. Westfall, and C.V. Cole. 1993. Agroecosystem approach to soil and crop management research. Soil Sci. Soc. Am. J. 57:1354-1360. doi:10.2136/sssaj1993.03615995005700050032x

Providoli, I., H. Bugmann, R. Siegwolf, N. Buchmann, and P. Schleppi. 2006. Pathways and dynamics of ${ }^{15} \mathrm{NO}_{3}^{-}$and ${ }^{15} \mathrm{NH}_{4}^{+}$applied in a mountain Picea abies forest and in a nearby meadow in central Switzerland. Soil Biol. Biochem. 38:1645-1657. doi:10.1016/j.soilbio.2005.11.019

R Development Core Team. 2013. R: A language and environment for statistical computing. Version 2.15.0 R Foundation for Statistical Computing, Vienna, Austria.

Robertson, D.M., and D.A. Saad. 2013. SPARROW models used to understand nutrient sources in the Mississippi/Atchafalaya River Basin. J. Environ. Qual. 42:1422-1440. doi:10.2134/jeq2013.02.0066

Robinson, D. 2001. $\delta^{15} \mathrm{~N}$ as an integrator of the nitrogen cycle. Trends Ecol. Evolution 16:153-162. doi: 10.1016/s0169-5347(00)02098-x

Schimel, D., M.A. Stillwell, and R.G. Woodmansee. 1985. Biogeochemistry of C, N, and P in a soil catena of the Shortgrass Steppe. Ecology 66:276-282. doi: $10.2307 / 1941328$

Schimel, D.S., W.J. Parton, F.J. Adamsen, R.G. Woodmansee, R.L. Senft, and M.A. Stillwell. 1986. The role of cattle in the volatile loss of nitrogen from a shortgrass steppe. Biogeochemistry 2:39-52. doi:10.1007/BF02186964

Sebilo, M., B. Mayer, B. Nicolardot, G. Pinay, and A. Mariotti. 2013. Long-term fate of nitrate fertilizer in agricultural soils. Proc. Natl. Acad. Sci. USA. 110:18185-18189. doi:10.1073/pnas.1305372110

Shaver, T.M., G.A. Peterson, L.R. Ahuja, D.G. Westfall, L.A. Sherrod, and G. Dunn. 2002. Surface soil physical properties after twelve years of dryland no-till management. Soil Sci. Soc. Am. J. 66:1296-1303. doi:10.2136/ sssaj2002.1296

Stewart, B.A., P. Koohafkan, and K. Ramamoorthy. 2006. Dryland agriculture defined and its importance to the world. In: G.A. Peterson and P.W. Unger, editors, Dryland agriculture. ASA, CSSA, and SSSA, Madison, WI. p. $1-26$.

Templer, P.H., M.C. Mack, F.S. Chapin, III, L.M. Christenson, J.E. Compton, H.D. Crook, et al. 2012. Sinks for nitrogen inputs in terrestrial ecosystems: A meta-analysis of ${ }^{15} \mathrm{~N}$ tracer field studies. Ecology 93:1816-1829. doi:10.1890/11-1146.1

West, T.O., and W.M. Post. 2002. Soil organic carbon sequestration rates by tillage and crop rotation: A global data analysis. Soil Sci. Soc. Am. J. 66:1930-1946. doi:10.2136/sssaj2002.1930

Wood, C.W., D.G. Westfall, G.A. Peterson, and I.C. Burke. 1990. Impacts of cropping intensity on carbon and nitrogen mineralization under no-till dryland agroecosystems. Agron. J. 82:1115-1120. doi:10.2134/agronj19 90.00021962008200060018x

Xue, D., J. Botte, B. De Baets, F. Accoe, A. Nestler, P. Taylor, et al. 2009. Present limitations and future prospects of stable isotope methods for nitrate source identification in surface- and groundwater. Water Res. 43:11591170. doi:10.1016/j.watres.2008.12.048

Yonker, C.M., D.S. Schimel, E. Paroussis, and R.D. Heil. 1988. Patterns of organic carbon accumulation in a semiarid shortgrass steppe, Colorado. Soil Sci. Soc. Am. J. 52:478-483. doi:10.2136/sssaj1988.03615995005200020032x 